\title{
Characterization of bacterium types isolated from commercial laying hen farms in Ogun State Nigeria
}

\author{
Oluwawemimo Adebowale ${ }^{1 *}$ Olanike Adeyemo²
}

\section{Keywords}

Poultry, laying hen, Bacteria, commercial farming, health hazard, Nigeria

Submitted: 23 January 2018

Accepted: 12 June 2018

Published: 29 October 2018

DOI: $10.19182 /$ remvt.31642

\section{Summary}

This study investigated the distribution of bacterium categories isolated from poultry feces and litters on commercial laying hen farms in Remo and Egba local government areas, Ogun State, Nigeria. In total 29 species of lactose and non-lactose fermenters were recovered. Bacteria isolated from feces included Aeromonas hydrophila (27.5\%), Providencia stuartii (15.5\%), Actinobacillus sp. (9.1\%), Burkholderia cepacia (7.7\%), Serratia marcescens $(4.9 \%)$, Citrobacter diversus (4.9\%), Klebsiella oxytoca (4.2\%), and Enterobacter gergoviae (4.2\%). Others were Escherichia coli (2.1\%), Plesiomonas shigelloides (2.1\%), Vibrio alginolyticus (2.1\%), Morganella morganii (2.1\%), Pantoea agglomerans (1.4\%), Vibrio mimicus $(1.4 \%)$, Pseudomonas aeruginosa (1.4\%), Burkholderia pseudomallei $(1.4 \%)$, Salmonella arizonae $(0.7 \%)$, Klebsiella pneumonia $(0.7 \%)$, Acinetobacter iwoffii $(0.7 \%)$, Vibrio vulnificus $(0.7 \%)$, Shewanella putrefaciens $(0.7 \%)$, Proteus mirabilis $(0.7 \%)$ and Proteus vulgaris $(0.7 \%)$. There was $66.7 \%$ similarity between the bacterium profile of litters and that of feces; some additional strains were identified in the litters. No variation $(p=0.64)$ was observed in the number of isolated bacterium types from feces and litter samples. However, the number of bacterium types isolated from fecal samples differed $(p=0.002)$ between the two studied areas. Results suggest that there is a potential risk of wide-range bacterial transmission within poultry populations, and to humans in close contact with them.

- How to quote this article: Adebowale O., Adeyemo O., 2018. Characterization of bacterium types isolated from commercial laying hen farms in Ogun State Nigeria. Rev. Elev. Med. Vet. Pays Trop., 71 (3): 137-141, doi: $10.19182 /$ remvt.31642

\section{INTRODUCTION}

The poultry industry in Nigeria has been rapidly expanding in past years despite having faced several challenges such as the avian influenza outbreak in 2006 (Fagbamila et al., 2017). However, prospects have been hampered by several factors such as morbidity and mortality caused by enteric bacterial diseases, which are on the increase in

\footnotetext{
1. Department of Veterinary Public Health and Reproduction, College of Veterinary Medicine, Federal University of Agriculture Abeokuta, Nigeria.

2. Department of Veterinary Public Health and Preventive Medicine, University of Ibadan, Nigeria.

* Corresponding author

Tel.: +234 (0)90 856080 43; Email: oluwawemimo1@yahoo.com
}

the poultry industry in Nigeria (Ojo et al., 2012). In addition, across the different regions of the country, the poultry sector is characterized by a low level of specialization and general weak level of biosecurity (Fagbamila et al., 2017).

Common bacterial diseases of poultry birds with huge impact on production and health in Nigeria include Escherichia coli, Salmonella serotypes and other enteric pathogens (Lutful Kabir, 2010). Apart from consequences on poultry production, many other species belonging to Enterobacteriaceae or non-Enterobacteriaceae have been implicated as opportunistic, nosocomial and foodborne pathogens responsible for a wide range of infections in humans, especially in critically ill or immunocompromised patients (Dowd et al., 2008; Gwida et al., 2014). Fecal contamination of poultry and poultry products with pathogens such as Salmonella, Escherichia coli, Proteus, Klebsiella, Enterobacter, Pseudomonas and others have shown to constitute problems in food hygiene and processing, with increasing poultry meat spoilage and pathogen dissemination to consumers 
(Davies and Board, 1998; Zhao et al., 2001; Gwida et al., 2014). Besides, the global increase in resistance of Gram-negative bacteria to common antibiotics used for treatments in animals and humans has generated a huge public health concern.

Acquiring information on Gram-negative bacterium strains and populations (both Enterobacteriaceae and non-Enterobacteriaceae) circulating or present on poultry farms in Ogun State would be useful to develop efficient on-farm and food-safety mitigation strategies, conduct effective monitoring and surveillance of pathogens and antibiotic resistance, and, ultimately, reduce human exposure to zoonotic and opportunistic pathogens from poultry and poultry products. For these major concerns, we investigated and described diverse enteric bacterium types (Gram-negative bacilli) present in poultry feces and litters from commercial laying hen farms in Egba and Remo local government areas of Ogun State, Nigeria.

\section{MATERIALS AND METHODS}

\section{Study area}

Ogun State has the highest concentration of poultry farms in Nigeria, particularly laying hen production; it is also known as the Gateway State and shares a border with Benin to the west, and interstate boundaries with Oyo to the north, Lagos to the south and Ondo to the east (Afolabi et al., 2013; Adebowale et al., 2016). The study area is located in the southwestern zone of the country between $6.20^{\circ}$ $7.80^{\circ} \mathrm{N}$ and $3.00-5.00^{\circ} \mathrm{E}$, and covers $16,409.26$ square kilometers.

\section{Survey design and farm recruitment}

A survey was conducted to determine and characterize the prevalence of enteric bacterium isolates from poultry farms in Ogun State. All registered commercial laying hen farms in the State were included in the population target. In total 113 such farms from Egba $(n=72)$ and Remo zones $(n=41)$ were selected and sampled based on address accessibility and farmers' willingness to participate (Figure 1). When the farms could not be accessed, we replaced them with other farms from the farm list.

The sample size was estimated according to Thrusfield (2007); the formula used was:

$n=Z^{2} \times P_{\exp }\left(1-P_{\exp }\right)$ $\mathrm{d}^{2}$

where $\mathrm{Z}$ is the degree of confidence (1.96), $\mathrm{P}$ the expected prevalence, and $d$ the precision at $95 \%$ confidence level (5\% in this study).

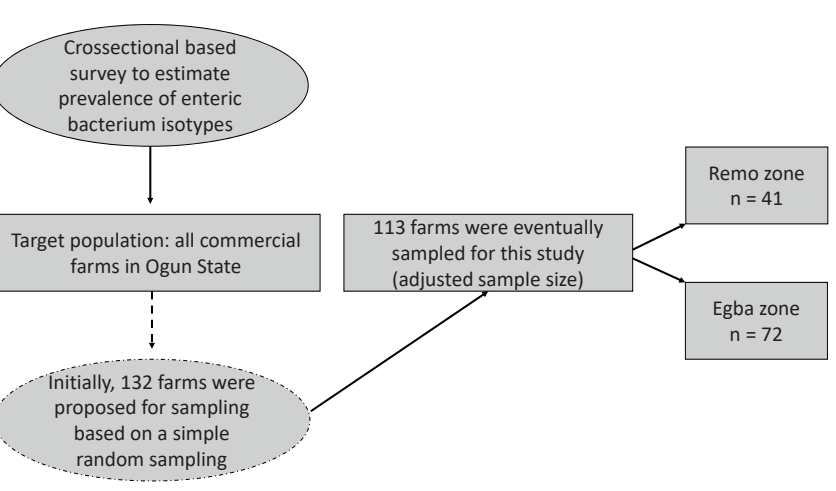

Figure 1: Recruitment flow chart of commercial poultry farms to characterize bacteria from feces and litters in Remo and Egba zones of Ogun State, Nigeria.
The adjusted sample size was estimated at 132 farms with expected frequency of at least $50 \%$, and $5 \%$ precision at $95 \%$ confidence level: $\mathrm{n}_{\mathrm{adj}}=\mathrm{Nxn} / \mathrm{N}+\mathrm{n}$

where $n_{\text {adj }}$ is the adjusted sample size, $N$ the sample size of the study population, $\mathrm{n}$ the sample size based on infinite population.

\section{Sample collection}

From each farm studied, five pooled fresh fecal droppings and poultry litters were randomly collected with sterile disposable gloves. Samples were labeled and transported in a cold box to the Department of Microbiology Laboratory, College of Veterinary Medicine, Federal University of Agriculture, Abeokuta, for microbiological examination. All samples were processed using conventional methods of cultivation.

\section{Bacterium isolation and characterization}

In total $2.5 \mathrm{~g}$ each of feces and litter were pre-enriched in $22.5 \mathrm{ml}$ buffered peptone water (CM0509, Oxoid, UK) and incubated at $37^{\circ} \mathrm{C}$ for 18-24 hours. Thereafter, aliquots (a loop full) of enriched broth were inoculated on prepared sterile MacConkey agar plates (CM0115, Oxoid) and incubated at $37^{\circ} \mathrm{C}$ for $18-24$ hours. Plates were observed for both lactose and non-lactose fermenting bacteria, with pink and straw-colored colonies, respectively. Discrete colonies were recultured on MacConkey agar plates. Purified isolates were identified and confirmed by using 24 different biochemical tests distributed in microplates (Microbact GNB 24E, Oxoid) and Microbact 2000 computer software package (Oxoid). Bacterial identification by Microbact is based on $\mathrm{pH}$ changes in various dehydrated substrates and substrate utilization (O'Hara, 2005). Briefly, according to the manufacturer's procedure, 1-3 colonies picked from each purified isolate were resuspended in physiological saline solution $(0.85 \% \mathrm{NaCl})$; four drops of bacterium suspension used to inoculate Microbact micro well plates were then added. Two drops of mineral oil (MB1093A) were added to black wells, seals were replaced over wells which were incubated at $35^{\circ} \mathrm{C} \pm 2^{\circ} \mathrm{C}$ for $18-24$ hours. Subsequently, reagents such as indole Voges-Proskauer (V-P1, V-P11) and tryptophan deaminase (TDA) were added to corresponding wells as instructed by the manufacturer. The reactions with visible color changes were converted into an octal code (base 8 number system from 0 to 7), which was then entered in the Microbact computerized identification package for identification (O'Hara, 2005). Substrates included in the identification kit were lysine, ornithine, $\mathrm{H}_{2} \mathrm{~S}$, glucose, mannitol, xylose, o-nitrophenyl- $\beta$-d-galactopyranoside (ONPG), indole, urease, V-P, citrate, TDA, nitrate, gelatin, malonate, inositol, sorbitol, rhamnose, sucrose, lactose, arabinose, adonitol, raffinose, salicin and arginine.

\section{Statistical analysis}

Prevalence with the 95\% confidence interval was determined using Graphpad Quickcalcs online software package. Non-parametric Mann Whitney U test was used to compare variations in the number of bacterium types from different sample categories. All results generated with $\mathrm{p}$ value less than 0.05 were considered statistically significant. All graphic presentations and analyses were performed by Graphpad Prism 6.07, and Microsoft Excel 2013.

\section{RESULTS}

A wide range of different bacterium species were isolated including seventeen species of Enterobacteriaceae, and twelve of non-Enterobacteriaceae. The main Enterobacteriaceae isolated from poultry feces were, with 95\% confidence interval (CI), Providencia stuartii (15.5\%; CI 10.4-22.4), S. marcescens (4.9\%; CI 2.2-10.0), 
Citrobacter diversus (4.9\%; CI 2.2-10.8), K. oxytoca (4.2\%; CI 1.79.1) and Enterobacter gergoviae (4.2\%, CI 1.7-9.1). Other types isolated included Pantoea agglomerans (4.2\%), Escherichia coli (2.1\%), Plesiomonas shigelloides (2.1\%), Morganella morganii (2.1\%), Salmonella arizonae $(0.7 \%)$, Klebsiella pneumoniae $(0.7 \%)$, Proteus mirabilis ( $0.7 \%$ ) and Proteus vulgaris (0.7\%) (Figure 2, top).

Furthermore, commonly isolated non-Enterobacteriaceae from feces included, with 95\% CI, Aeromonas hydrophila (27.5\%; CI 20.8-35.4), Actinobacillus species (9.1\%; CI 5.3-15.1), Burkholderia cepacia (7.7\%; CI 4.3-13.4), Vibrio alginolyticus (2.1\%), Vibrio mimicus (1.4\%), Pseudomonas aeruginosa (1.4\%), Burkholderia pseudomallei (1.4\%), Acinetobacter iwoffii (0.7\%), Vibrio vulnificus (0.7\%), Shewanella putrefaciens $(0.7 \%)$. Overall, Aeromonas hydrophila was the most isolated species from feces samples (Figure 2, top).

With regard to litter samples, there was $66.7 \%$ similarity with bacterium profiles isolated from poultry feces, except for a few strains such as Flavobacterium meningosepticum, Hafnia alvei and Moraxella sp. The main Enterobacteriaceae identified from litters was, with $95 \%$ CI, Klebsiella oxytoca (11.5\%; CI 6.3-20.3). Moreover, the most frequently isolated non-Enterobacteriaceae were Aeromonas hydrophila (22.1\%; CI 14.6-32.0) and Pseudomonas aeruginosa (11.4\%; CI 6.3-20.3) (Figure 2, bottom). No variation ( $\mathrm{p}=0.64$ ) was observed in the number of bacterium types isolated from poultry feces and litter samples. However, there was a difference $(\mathrm{p}=0.002)$ between the two studied areas in the number of bacterium types isolated from fecal samples (Figure 2, bottom).

\section{DISCUSSION}

Poultry farming has contributed to the economy of many countries and accounts for $25 \%$ of local meat production in Nigeria. However, productivity of poultry is faced with various disease challenges especially caused by enteric pathogens (Mshelbwala et al., 2017). There are limited data that show the distribution of various enteric bacterium types belonging to Enterobacteriaceae and non-Enterobacteriaceae in commercial laying hen farms in Ogun State, except in free-range local chickens (Ojo et al., 2012).

The present study was carried out to determine the distribution of various Gram-negative bacterium types of Enterobacteriaceae and non-Enterobacteriaceae in commercial laying hen farms in Ogun State. Microbact was used to group isolated bacteria because of its availability, cost (relatively cheap), and capacity to identify miscellaneous Enterobacteriaceae and other Gram-negative bacilli present in diverse biological samples. Microbact is reported to be very accurate and useful in routine flow work in microbiology, and a convenient means of identifying members of the family Enterobacteriaceae (Mugg and Hill, 1981).

In the study, most common Gram-negative rod-shaped bacteria identified belonged to the family Enterobacteriaceae or to non-Enterobacteriaceae - a few of which are highly pathogenic and associated with gastroenteritis and pneumonia in humans and animals. Others were opportunistic or nosocomial pathogens, which are clinically important and commonly found in the urinary or respiratory tract of critically ill or immunocompromised people. A study conducted by Kilonzo-Nthenge et al. (2013), which evaluated drug-resistant Enterobacteriaceae in retail poultry meat and beef showed that meat samples were contaminated with similar bacterium types isolated in our study. Such potential pathogenic bacterium types included Escherichia coli, Enterobacter aerogenes, Hafnia alvei, Klebsiella oxytoca, Klebsiella pneumoniae, Kluyvera sp., Morganella morganii, Vibrio parahaemolyticus, Yersinia enterocolitica and Salmonella sp. to mention a few. Klebsiella oxytoca was identified as the most commonly isolated pathogen in chicken and turkey meat (Kilonzo-Nthenge et al., 2013). Poultry meat becomes contaminated with gastrointestinal flora during processing and may serve as a vehicle for foodborne pathogens. Sabarinath et al. (2009) described similar strains as major contaminants in commercial chicken in the West Indies. Interestingly, unlike these two studies, the present study showed that Providencia stuartii was the most commonly isolated Enterobacteriaceae in poultry feces.
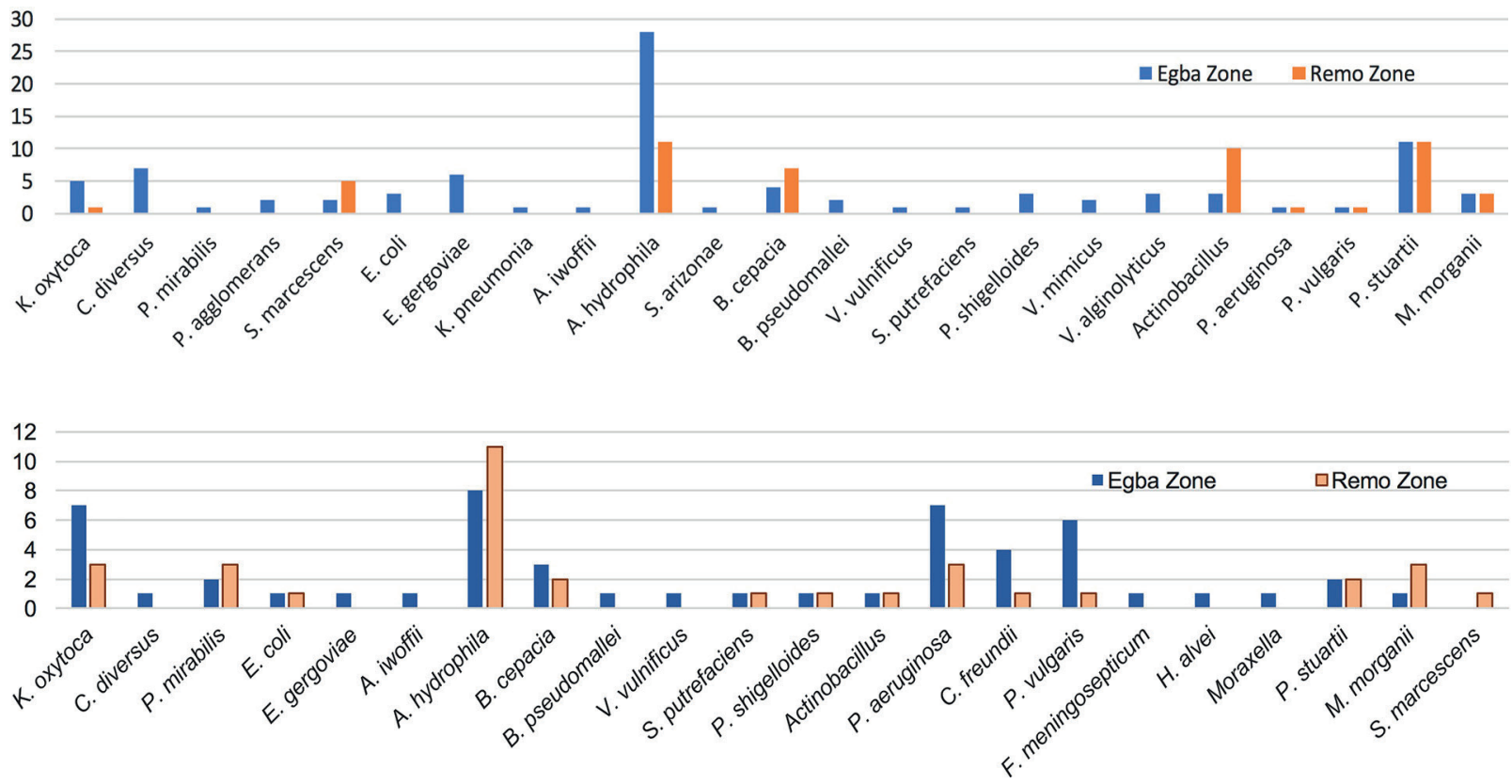

Figure 2: Distribution of bacterium types isolated from feces (top) and litters (bottom) on commercial laying hen farms in Remo and Egba zones of Ogun State, Nigeria. Klebsiella oxytoca; Citrobacter diversus; Proteus mirabilis; Pantoea agglomerans; Serratia marcescens; Escherichia coli; Enterobacter gergoviae; Klebsiella pneumonia; Acinetobacter iwoffii; Aeromonas hydrophila; Salmonella arizonae; Burkholderia cepacia; Burkholderia pseudomallei; Vibrio vulnificus; Shewanella putrefaciens; Plesiomonas shigelloides; Vibrio mimicus; Vibrio alginolyticus; Actinobacillus; Pseudomonas aeruginosa; Proteus vulgaris; Providencia stuartii; Morganella morganii; Citrobacter freundii; Flavobacterium meningosepticum; Hafnia alvei; Moraxella. 
Providencia stuartii is reported to be isolated from human feces, burns, wounds, animals especially poultry, reptiles and the environment (Liu, 2011). Unlike the more pathogenic members of Enterobacteriaceae (Salmonella, Escherichia coli or Shigella) which have been widely studied, $P$. stuartii is a normal intestinal microflora of animals and humans but of clinical importance because of its implication in nosocomial infection outbreaks in communities and hospitals (Liu, 2011). It can cause severe infections in humans (especially in immunocompromised individuals), which range from diarrhea, urinary tract infections, endocarditis to septicemia (AlJehani et al., 2012). Infections are usually fatal because of its marked resistance to multiple antibiotics (Liu, 2011; AlJehani et al., 2012). This pathogen has been associated with poultry diseases and, like other Enterobacteriaceae, constitutes a major problem in meat hygiene and processing due to contamination and spoilage (Davies and Board, 1998).

Other similar intestinal microfloras isolated from this study were Proteus, Morganella, Citrobacter, Hafnia, and Serratia. Furthermore, the presence of E. coli, Salmonella, and Klebsiella pneumoniae in poultry samples poses great economic and public health concern in terms of high mortality rate in birds associated with colibacillosis, salmonellosis, respiratory tract infections, and food safety (Miranda et al., 2008). For instance, E. coli is associated with diarrhea caused by varying enteropathogenic, enterotoxigenic, enteroinvasive, enterohemorrhagic and enteroaggresive pathotypes. The presence of these highly pathogenic bacteria in feces and litter could prompt propagation within bird populations, and contamination of the environment and of the poultry food chain during processing, handling, or packaging of finished products (Miranda et al., 2008). Isolation of multiple pathogens on different farms in the studied areas also points to the poor sanitary conditions and biosecurity measures on many poultry farms in Nigeria. Improved hygiene primarily at farm level may be crucial to controlling the risk of bacterium propagation along the food chain.

With regard to non-Enterobacteriaceae from feces and litter samples Aeromonas hydrophila was the most isolated. This is not a surprise as Aeromonas have been reported particularly in poultry and isolated from sick and healthy commercial chickens in several studies conducted in Nigeria (Mailafia and Nok, 2009; Adeleke and Omafuvbe, 2009). A. hydrophila is considered as an opportunistic pathogen in poultry and incriminated in cases of fowl cholera outbreaks, a devastating disease in chickens in Nigeria (Mailafia and Nok, 2009). Furthermore, A. hydrophila has emerged as an important human pathogen associated with foodborne disease outbreaks and gastroenteritis ranging from mild diarrhea to cholera-like disease (Awaad et al., 2011; Evangelopoulou et al., 2015). Other than gastroenteritis, Aeromonas is responsible for meningitis, cellulitis, otitis, endocarditis, osteomyelitis, peritonitis, bacteremia, and septicemia, among other diseases (Albert et al., 2000). Considering in this study the high farm-level prevalence of $A$. hydrophila, people in close contact with birds especially poultry workers could be at high risk of exposure to infection, and dissemination. A study in Brazil reported a high prevalence of A. hydrophila in asymptomatic poultry farmers (18.5\%), four of the farms studied had $50-75 \%$ of the workers contaminated, and $75 \%$ of farmers positive to the pathogen experienced frequent gastroenteric disorders (Zanella et al., 2012). In view of the present results, it is suggested that further work to investigate the prevalence of this pathogen in those closely in contact with poultry and reported cases of gastroenteritis should be conducted to evaluate public health and socioeconomic impacts.

Having an insight into the bacterium diversity of poultry farms would enable to develop efficient pathogen surveillance systems, mitigation strategies or guidance for reducing on-farm zoonotic and opportunistic pathogens. In addition, mortality or morbidity associated with infections and resistance, potential transmission to people working closely with poultry especially poultry workers or handlers or veterinarians, and associated food safety consequences would be reduced.

\section{CONCLUSION}

The present study reported the presence of various potentially pathogenic bacteria belonging to Enterobacteriaceae and non-Enterobacteriaceae from laying hen litters and feces in Ogun State commercial farms. It suggests a potential risk of wide-range bacterial transmission within poultry populations to humans in close contact with poultry, and to consumers. Data from this study aimed to provide information for monitoring and system surveillance of farms for pathogens, and formulation of operable guidance and policies for reducing on farm pathogen presence, transmission and risk of exposure to the wider community. Further evaluation and susceptibility pattern of these isolates to commonly used antibiotics in the poultry industry in Ogun State may be needed.

\section{Acknowledgments}

The authors wish to thank Mr. P.A. Akinduti and Mrs. E. Kperegbeyi for technical assistance during this study.

\section{REFERENCES}

Adebowale O.O., Adeyemo O.K., Awoyomi O., Dada R., Adebowale O., 2016. Antibiotic use and practices in commercial poultry laying hens in Ogun State Nigeria. Rev. Elev. Med. Vet. Pays Trop., 69 (1): 41-45, doi: 10.19182/ remvt. 31170

Albert M.J., Ansaruzzaman M., Talukder K.A., Chopra A.K., Kuhn I., Rahman M., Mollby R., 2000. Prevalence of enterotoxin genes in Aeromonas spp. isolated from children with diarrhea, healthy controls, and the environment. J. Clin. Microbiol., 38 (10): 3785-3790

AlJehani Y., Albuainain H., Zakaria H., Makhdom F., Al-Ansari R., 2012. Necrotizing fasciitis: An unusual causative pathogen; A case report. Int. J. Health Allied Sci., 1 (4): 286-289, doi: 10.4103/2278-344X.107899

Davies A., Board R., 1998. The microbiology of meat and poultry. Aspen, Gaithersburg, MD, USA

Dowd S.E., Callaway T.R., Wolcott R.D., Sun Y., McKeehan T., Hagevoort R.G., Edrington T.S., 2008. Evaluation of the bacterial diversity in the feces of cattle using $16 \mathrm{~S}$ rDNA bacterial tag-encoded FLX amplicon pyrosequencing (bTEFAP). BMC Microbiol., 8: 125, doi:10.1186/1471-2180-8-125

Evangelopoulou G., Filioussis G., Kritas S., Kantere M., Burriel A.R., 2015. Isolation and antimicrobial testing of Aeromonas sp., Citrobacter sp., Cronobacter sp., Enterobacter sp., Escherichia sp., Klebsiella sp., and Trabulsiella sp.from the gallbladder of pigs. Pol. J. Microbiol., 64 (2): 185-8

Fagbamila I.O., Barco L., Mancin M., Kwaga J., Ngulukun S.S., Zavagnin P., Lettini A.A., et al., 2017. Salmonella serovars and their distribution in Nigerian commercial chicken layer farms. PLoS One 12 (3): e0173097, doi: 10.137 1/journal.pone.017309

Gwida M., Hotzel H., Geue I., Tomaso H., 2014. Occurrence of Enterobacteriaceae in raw meat and in human samples from Egyptian retail sellers. Int. Schol. Res. Notices, 2014, 565671, doi: 10.1155/2014/565671

Kilonzo-Nthenge A., Rotich E., Nahashon S.N., 2013. Evaluation of drugresistant Enterobacteriaceae in retail poultry and beef. Poult. Sci., 92: 10981107

Liu D., 2011. Molecular detection of human bacterial pathogens. CRC Press, 1278 p.

Lutful Kabir, S.M., 2010. Avian colibacillosis and salmonellosis: A closer look at epidemiology, pathogenesis, diagnosis, control and public health concerns. Int. J. Environ. Res. Public Health, 7 (1): 89-114, doi: 10.3390/ijerph7010089 
Mailafia S., Nok A., 2009. Spectrophotometric determination of proteins associated with virulence in Nigerian strains of Aeromonas species. Bayero. J. Pure. Appl. Sci., 2 (1): 105-108

Miranda J.M., Guarddon M., Mondragon A., Vázquez B.I., Fente C.A., Cepeda A., Franco C.M., 2007. Antimicrobial resistance in Enterococcus spp. strains isolated from organic chicken, conventional chicken, and turkey meat: a comparative survey. J. Food Prot., 70 (4): 1021-1024

Mshelbwala F.M., Ibrahim N.D., Saidu S.N., Azeez A.A., Akinduti P.A., Kwanashie C.N., Kadiri A.K.F., et al., 2017. Motile Salmonella serotypes causing high mortality in poultry farms in three South-Western States of Nigeria. Vet. Rec. Open, 4: e000247

Mugg P., Hill A. 1981. Comparison of the Microbact-12E and 24E systems and the API-20E system for the identification of Enterobacteriaceae. J. Hyg. Camb., 87 (2): 287-97, doi: 10.1017/S0022172400069503

O'Hara C.M., 2005. Manual and automated instrumentation for identification of Enterobacteriaceae and other aerobic Gram-negative bacilli. Clin. Microbiol. Rev., 18 (1): 147-62, doi: 10.1128/CMR.18.1.147-162.2005
Ojo O.E., Awosile B., Agbaje M., Sonibare A.O., Oyekunle M.A., Kasali O.B., 2012. Quinolone resistance in bacterial isolates from chicken carcasses in Abeokuta, Nigeria: A retrospective study from 2005-2011. Nig. Vet. J., 33 (2): 483-491

Sabarinath A., Guillaume V., Guillaume B., Mathew V., DeAllie C., 2009. Bacterial contamination of commercial chicken eggs in Grenada, West Indies. West Indian. Vet. J., 9 (2): 4-7

Thrusfield M., 2007. Veterinary epidemiology. Blackwell Publishing, 610 p.

Zanella J. de F.P., da Luz R.B., Fadanelli R., Figueir M.P., Delamare A.P.L., da Costa S.O.P., Echeverrigaray S., 2012. High prevalence of Aeromonas spp. in poultry farmers from a rural community of South Brazil. Asia Pac. J. Mol. Biol. Biotechnol., 20 (3): 93-98

Zhao C., Ge B., De Villena J., Sudler R., Yeh E., Zhao S., Meng J., 2001 Prevalence of Campylobacter spp., Escherichia coli, and Salmonella serovars in retail chicken, turkey, pork, and beef from the Greater Washington, D.C., area. Appl. Environ. Microbiol., 67 (12): 5431-5436, doi: 10.1128/ AEM.67.12.5431-5436.2001

\section{Résumé}

Adebowale O., Adeyemo O. Caractérisation des types de bactéries isolés dans des élevages de poules pondeuses commerciales de l'Etat d'Ogun, Nigeria

L'étude a porté sur la répartition des types de bactéries isolées à partir de fèces et de litières de volaille dans les élevages commerciaux de poules pondeuses des agglomérations de Remo et d'Egba, Etat d'Ogun, Nigeria. Au total, 29 espèces de fermenteurs du lactose et de non-fermenteurs du lactose ont été récoltées. Les bactéries isolées des fèces comprenaient Aeromonas hydrophila (27,5\%), Providencia stuartii (15,5\%), Actinobacillus sp. (9,1\%), Burkholderia cepacia (7,7 \%), Serratia marcescens $(4,9 \%)$, Citrobacter diversus $(4,9 \%)$, Klebsiella oxytoca (4,2\%) et Enterobacter gergoviae (4,2\%). Les autres espèces étaient Escherichia coli (2,1\%), Plesiomonas shigelloides $(2,1 \%)$, Vibrio alginolyticus (2,1\%), Morganella morganii (2,1\%), Pantoea agglomerans (1,4\%), Vibrio mimicus $(1,4 \%)$, Pseudomonas aeruginosa $(1,4 \%)$, Burkholderia pseudomallei $(1,4 \%)$, Salmonella arizonae $(0,7 \%)$, Klebsiella pneumonia $(0,7 \%)$, Acinetobacter iwoffii $(0,7 \%)$, Vibrio vulnificus $(0,7 \%)$, Shewanella putrefaciens $(0,7 \%)$, Proteus mirabilis $(0,7 \%)$ et Proteus vulgaris $(0,7 \%)$. Il y avait $66,7 \%$ de similarité entre le profil bactérien des litières et celui des fèces ; quelques souches supplémentaires ont été identifiées dans les litières. Aucune variation $(p=0,64)$ n'a été observée dans le nombre de types de bactéries isolés provenant d'échantillons de fèces et de litières. Cependant, le nombre de types de bactéries isolés à partir des matières fécales a été significativement différent $(p=0,002)$ entre les deux zones étudiées. Les résultats suggèrent qu'il existe un risque potentiel de transmission bactérienne à grande échelle au sein des populations de volailles, et aux humains qui y sont en contact étroit.

Mots-clés : volaille, poule pondeuse, Bacteria, agriculture commerciale, danger pour la santé, Nigeria

\section{Resumen}

Adebowale O., Adeyemo O. Caracterización de tipos de bacterias aisladas en granjas de gallinas ponedoras comerciales en el estado de Ogun, Nigeria

Este estudio investigó la distribución de categorías de bacterias aisladas de heces y camas de aves de corral en granjas comerciales de gallinas ponedoras en áreas de gobierno local de Remo y Egba, estado de Ogun, Nigeria. En total se recuperaron 29 especies de fermentadores de lactosa y no lactosa. Las bacterias aisladas de las heces incluyeron Aeromonas hydrophila $(27,5 \%)$, Providencia stuartii $(15,5 \%)$, Actinobacillus sp. (9,1\%), Burkholderia cepacia $(7,7 \%)$, Serratia marcescens $(4,9 \%)$, Citrobacter diversus $(4,9 \%)$, Klebsiella oxytoca $(4,2 \%)$ y Enterobacter gergoviae (4,2\%). Otras fueron Escherichia coli $(2,1 \%)$, Plesiomonas shigelloides $(2,1 \%)$, Vibrio alginolyticus (2,1\%), Morganella morganii $(2,1 \%)$, Pantoea agglomerans $(1,4 \%)$, Vibrio mimicus $(1,4 \%)$, Pseudomonas aeruginosa $(1,4 \%)$, Burkholderia pseudomallei $(1,4 \%)$, Salmonella arizonae $(0,7 \%)$, Klebsiella pneumonia $(0,7 \%)$, Acinetobacter iwoffii $(0,7 \%)$, Vibrio vulnificus $(0,7 \%)$, Shewanella putrefaciens $(0,7 \%)$, Proteus mirabilis $(0,7 \%)$ y Proteus vulgaris $(0,7 \%)$. Hubo una similitud del $66,7 \%$ entre el perfil de bacterias de las camas y el de las heces; algunas cepas adicionales fueron identificadas en las camas. No se observó variación $(p=0,64)$ en el número de tipos de bacterias aisladas de heces y camas. Sin embargo, el número de tipos de bacterias aisladas de muestras fecales difirió $(p=0,002)$ entre las dos áreas estudiadas. Los resultados sugieren que existe un importante riesgo potencial de transmisión bacteriana entre las poblaciones de aves de corral, y para los humanos en contacto cercano con ellas.

Palabras clave: ave de corral, gallina ponedora, Bacteria, agricultura comercial, peligro para la salud, Nigeria 
